\title{
FEASIBILITY STUDY OF RELIGION TOURISM BUSINESS FOR THE YOUNG PEOPLE
}

\author{
Apriliana Lailatul Nur Sahita \\ alailatul@magister.ciputra.ac.id \\ Tina Melinda \\ Faculty of Business and Management, Ciputra University \\ Citraland CBD Boulevard, Surabaya 60219, Indonesia
}

received: 22/12/17; revised: 24/05/18; published: 27/06/18

\begin{abstract}
The goal of the research is to find out the feasibility of the development of the travel service business and backpacker Umrah Easy Trip that was developed by young people. It is reviewed based on five aspects of business feasibility study including: market aspect, legal aspect, technical and technological aspect, management aspect and financial aspect. A qualitative approach is used in this study by using the interview. Five interviewees consisting of three owners of backpacker Umrah service and two consumers of backpacker Umrah. Result of the study mentioned that the business of backpacker Umrah is reasonable to be run and developed if it is reviewed of the five aspects of the business feasibility study, namely: market aspect, legal aspect, technical aspect and technological aspect, management aspect and financial aspect. Easy Trip should learn from business owners who already ran the backpacker Umrah to develop backpacker Umrah who has already pioneered.
\end{abstract}

Keywords: backpacker umrah, business feasibility study

\section{INTRODUCTION}

Indonesian society amounted 262 million population, $85 \%$ of the population have the religion of Islam. The large population makes the opportunity and the chance to make a bussiness targetting the very large Muslim population in Indonesia. The trend of increasing Umrah worship in fact, becomes a prospective field for the travel agencies of Umroh and Hajj. Many young people perform Umrah worship together with their parents or relatives. About $10 \%$ to $15 \%$ among the young muslim women carry out the Umrah.

In this study, the researcher performed a business feasibility study analysis on the travel agency Easy Trip by doing a study on five aspects of the feasibility namely market, legal, technical and technological, management, and financial. Travel agency like tourism enterprises act at the local level, but operate in a global market place, this poses both opportunities and challenges (OECD, 2017). Easy Trip Travel Service Agency is a company that was established on 25 January 2016 providing trip traveling. Easy Trip is located in Surabaya and has business targets of middle and upper secondary segmentation because if it is seen from the data elaborated above, it can be inferred that the interest of young people or the age of 15-29 years old have a high interest towards Umrah worship because it follows a growing trend in 2016-2017. Based on the formulation of the problem that is developed above, the purpose of this research is to find out the development feasibility of the service business of travel and backpacker Umrah company Easy Trip developed by young people.

Market analysis and marketing aims are to understand how large the potential market is available, how much is the part that can be won by the company or a proposed venture, as well as marketing strategy planned for the consumer (Muhammad, 2012). Kotler (2012) classify the marketing mix into four large groups called $4 \mathrm{P}$ of marketing namely product, price, place, and promotion. In particular, the legal aspect of social, economic and cultural less attention from the initiator nor the framers of the feasibility study of the project. Whereas, in actual fact, this aspect precisely became the basis of the other aspect in determining the eligibility of a project investment. It is not rare to cancel a project built bump the issue of legality, claim from the local community and so on.

According to Suliyanto (2012), there are several types of legal entities which may be set up in Indonesia, namely individuals, Firm (Fa), Commanditaire Vennootschap (CV), a limited liability company (PT). The licensing requirements for each is different and is set out in government regulations that apply. Technical 
aspect with regard to the process of development the project is technically and organized after the project is completed (Muhammad, 2012). Technical aspect relating to the selection of the location of the project, the type of machine, or other equipment that suits the production capacity, layout and technology selection to production (Umar, 2012). Capacity is defined as the limiting the ability of a unit to produce in a given time. Layout or also called spatial, namely placement of facilities which is used in the factory such as the layout of the machinery, the layout of the means of production, transportation and so on. Layout of a variety of such facilities should be examined, in order to make the production process run effectively and efficiently (Umar, 2012).

Analysis of the management aspect is performed to obtain the image of the staff capabilities in conducting the business which is run. This analysis to study the organizational structures that correspond to the planned effort, so that it is known about the number of needs, qualifications and descriptions of individual tasks to manage the project (Kadariah, 2012). The study of aspect of management include the preparation of a plan of work, anyone who is involved, how to coordinate and oversee the implementation effort, determine effectively and efficiently about the form of business entity, the kinds of work, organizational structure as well as the procurement of the required workforce. In addition, according to Suryana (2013), it should be also noted whether the venture will be managed by yourself or involve others in a professional manner. Financial analysis is an analysis that compares whether a project is profitable for age project (Muhammad, 2012). Analysis of risk that will be examined include: 1) excessive production costs, 2) overheads Costs are high, 3) excessive Debt, and 4) excessive Loans. Financial analysis related to the source of the funds (investment) which will be retrieved and projected returns with the level of capital costs (costs which will be incurred) and the source of funds is concerned. Financial analysis that examined is the Payback Period, and Net Present Value.

This research uses qualitative approach to analyze technical aspect, marketing aspect, and financial aspect of doing business feasibility analysis (Roziq, 2016), uses the financial aspect by measuring Net Present Value, Internal Rate of Return and Payback period in accordance with the research of Immanuel (2016).

\section{METHODS}

This research uses qualitative approach, to collect data done by interview to competitor and consumer. Competitors who become resource persons have been doing business travel umroh for more than 3 years and also offers umroh backpacker service. Located in Surabaya, the criteria of the consumer is in the age between 15-29 years old. It never carried out backpacker activities umroh. The study was conducted in Surabaya from July 2017 - October 2017.

Data collection techniques are used namely using structured interviews and documentation. Researcher will prepare a list of questions relating to the aspect of business feasibility study. Therefore, the researcher can understand clearly the information that will be received. Instruments that will support: the structured interview recorders and cameras. The following are the methods of collecting data on every aspect.

Test the validity of the data on the qualitative method through the test reliability and validity data. Reliability test done with the audit to the overall research process. This study uses triangulation to obtain valid and reliable data. The inductive method is applied with the aim of taking a conclusion based on five aspects of feasibility study of business development namely marketing aspect, legal aspect, operational management aspect, technical and technological aspect and financial aspect. Data obtained from the result of the five mentioned aspects linked to the research foundation, namely the development feasibility of religious tourism business for young people.

\section{RESULTS AND DISCUSSION}

The young people are our new target. The idea came to create a travel agent with additional packages with the theme of "Backpacker". Backpacker do not organize in the country of origin, they prefer to arrange everything themselves (Hannert, 2010). With this new innovation, the researcher can attract young people to be more interested and can become a top priority for them to travel to a foreign country, especially religious tourism. In the young people's mind, religious tourism is considered as a relative expensive travel and it is impressed too serious which is identical to travel with family or parents. The existence of a Backpacker Umrah, the communities want the more relax impression without ignoring the worship which becomes the main goal of tourism itself, so Easy Trip wants to do business feasibility study backpacker Umrah.

Data retrieval in the study was obtained from interview result with the different informants. The total of informants in the research is 5 (five) persons who meet the criterias of informant who had set earlier. There were 2 interview informants in this research, they are the competitor's consumers who had experience with backpacker traveling and three business owners who has been already running the business for three years. The researcher wants to acquire the information result from competitor's consumers to know what aspects the consumers consider when selecting a backpacker Umrah service. The researcher wants to know how the feasibility of backpacker Umrah business is by conducting interviews with the three competitors of backpacker Umrah. 
Environmental factors in the growing multitude of young people in Surabaya who wants to go Umrah but also want the tour to other destinations will make a request service. Here is the formula of market aspect of Easy Trip in terms of STP, namely segmentation, target and positioning. (1) Segmenting. Segmentation that taken by backpacker Umrah Easy Trip is the intermediate and upper intermediate. Intermediate segmentation is chosen because this group has a lot of young people who want to Umrah because it follows the trend so like Umrah with a minimal budget. (2) Targeting. Target that becames backpacker Umrah is a community of Islamic students at a University, a Qur'an Recital community of young people, and the community of mothers. The young people became the main target because they follow the trend Umrah and backpacker are not too formal and can do another tour. (3) Positioning. Easy Trip which is a new player in the services of backpacker Umrah Easy Trip positioning itself into a focus on services offered. Easy Trip presents backpacker Umrah with a choice that can be requested by consumers and select destinations after the mandatory Umrah activities, so that not only is doing Umrah but also travel to other places.

Here is the formula of market aspect of Easy Trip in terms of $4 \mathrm{P}$ that is product, price, promotion and place. (1) Products. Products or services offered by Easy Trip is a backpacker umroh with finished goods destinations or in accordance with budget and consumer desires. Consumers are given standardized service options but can also provide the offer they want. (2) The price. Easy Trip with the price which is not too far away with another travel between Rp 15 million to Rp 20 million. But that price is just Umrah worship only, not including other destination. (3) Promotion. The promotion program will be done by Easy Trip is marketing through online and offline media. For offline media, Easy Trip will distribute brochures, pamphlets, the installation of billboards in front of the offices, participation in the exhibition tour and travel are increasingly evident in Surabaya, as well as participation in the event as youngster concert. Media offline promotion that will be used is to create a website, instagram, twitter, facebook page and also the line @ to target young people are now oriented in social media. (4) Location. Location of the Easy Trip is easy to find in the side of the road of Western Surabaya, therefore it is not difficult to find the location. It is not difficult to find a a parking space because Easy Trip has he availability of ample parking. Easy Trip provides convenience for consumers if it could not come at a location, simply booking over the phone and in eligibility will be assisted by Easy Trip until all requirements are met.

Based on interviews and measurements, it can be stated that the feasibility of backpacker business for the category of market aspect is feasible to do and develop (Table 1). Marketers should take into account cultures of Islamic countries when designing travelling and tourism packages, like halal tourism in flights, hotels,
Tabel 1. Criteria Market Aspect

\begin{tabular}{|c|c|c|c|}
\hline No & $\begin{array}{l}\text { Assessment } \\
\text { Criteria }\end{array}$ & $\begin{array}{c}\text { Eligible/ } \\
\text { Not Eligible }\end{array}$ & Description \\
\hline 1 & $\begin{array}{l}\text { Required product } \\
\text { customers }\end{array}$ & Eligible & $\begin{array}{l}\text { The backpacker } \\
\text { Umrah is a required } \\
\text { service customer who } \\
\text { like to Umrah but can } \\
\text { also make a tour }\end{array}$ \\
\hline 2 & $\begin{array}{l}\text { The existence of } \\
\text { market share and } \\
\text { competition. }\end{array}$ & Eligible & $\begin{array}{l}\text { Yet many competitors } \\
\text { in Surabaya }\end{array}$ \\
\hline 3 & $\begin{array}{l}\text { External environ- } \\
\text { mental factors and } \\
\text { macroeconomic } \\
\text { can affect demand } \\
\text { for new products. }\end{array}$ & Eligible & $\begin{array}{l}\text { Surabaya is a growing } \\
\text { environment continues } \\
\text { to make Easy Trip } \\
\text { creates the needed } \\
\text { services in society. }\end{array}$ \\
\hline
\end{tabular}

Source: Data Processed, (2017)

foods, and entertainments, call for prayer, providing the Holy Quran, and so on (Namin, 2013).

Based on the results of the interview with the speaker, the speaker has had all kinds of licenses such as a business license, NPWP, SIUP, TDP and also recorded on the Ministry of religious affairs. The service they offer is indeed more expensive with an Easy Trip but the legality of business that they have is equal to the services they provide. Easy Trip does not yet have a business license, TDP and SIUP, however already have NPWP references an individually on the owner or on the officers. This makes it an Easy Trip was doing the making of legality in order to complement the legal documents so that it can get more consumer confidence. The legality of the effort takes it to convince the consumer in order to believe in and use their travel. Based on interviews and observations, it can be stated that the feasibility of doing business backpacker in category legal aspect deserve to be run and developed (Table 2).

Tabel 2 Criteria Feasibility Law Aspect

\begin{tabular}{|c|c|c|c|}
\hline No & $\begin{array}{l}\text { Assessment } \\
\text { Criteria }\end{array}$ & $\begin{array}{c}\text { Eligible/ } \\
\text { Not Eligible }\end{array}$ & Description \\
\hline 1 & Legal entity & Eligible & $\begin{array}{l}\text { Have a legal entity } \\
\text { with a partner }\end{array}$ \\
\hline 2 & $\begin{array}{l}\text { Legality of Umrah } \\
\text { implementation }\end{array}$ & Eligible & $\begin{array}{l}\text { Legality is already } \\
\text { trusted }\end{array}$ \\
\hline 3 & $\begin{array}{l}\text { The identity of } \\
\text { employers clearly }\end{array}$ & Eligible & $\begin{array}{l}\text { Employers provide } \\
\text { clear information }\end{array}$ \\
\hline 4 & $\begin{array}{l}\text { Clear business } \\
\text { location }\end{array}$ & Eligible & $\begin{array}{l}\text { Real business } \\
\text { location }\end{array}$ \\
\hline 5 & $\begin{array}{l}\text { The opening is } \\
\text { clear }\end{array}$ & Eligible & $\begin{array}{l}\text { Time hours operates } \\
\text { in accordance }\end{array}$ \\
\hline 6 & $\begin{array}{l}\text { The company's } \\
\text { operations are } \\
\text { clearly }\end{array}$ & Eligible & $\begin{array}{l}\text { The company's } \\
\text { operations could be } \\
\text { accounted for }\end{array}$ \\
\hline
\end{tabular}

Source: Data Processed, (2017) 
Technical aspect is useful to facilitate consumers in reaching out to the business location. The following are the assumptions and technical aspect of the technology that will be run and developed by Easy Trip. (1) Location layout. Location layout of Easy Trip who were on the side of the road, as well as close to the center of the crowd made it easy for customers to find the location of this travel agency because there are huge billboards showing the location of Easy Trip. The location can also be accessed through Google Maps, however Easy Trip has not still registered its locations for business tools on google maps. (2) For the future, Easy Trip will register the location of the business in Google so that consumers will have no trouble finding the location. (3) Service of process. Service of process begins from the parking attendants that appears when it is really needed. Parking attendants will do their job so well that consumers would not be ranting about the parking service available. (3) Facility Capacity. Maximum parking facility can only accommodate 10 cars and 20 motorcycles, while for the capacity of the waiting room can only accommodate 30 people. Easy Trip also provided 3 counters with different purposes where the service can reach 30 minutes depending on the needs of each consumer. (4) Building. The building is quite new and seem simple to make consumers comfortable because the building has a billboard and neon box that can make it easy for customers to find it.

The ease of the location makes the consumer trust the business because the location is easy to find. Although sales marketing or agents also serve customers, there are several things to be done at the business location. Placement of strategic business location, service process, consumer capacity in the waiting room and facilities provided in the business location will determine whether the building is feasible or not. Based on interviews and observation results, it can be stated that the business feasibility of backpacker Umrah in the category of technical aspects is considered feasible to be done and developed (Table 3). Every examination of technical feasibility is preceded by a comprehensive analysis of the task, the system, and the 'systems' environment (Bause, et.al., 2014).

Aspect of the operational management needs estimation, planning the recruitment of labor and also the planning and control of the business. Here is the assumption of the management and operational aspect of Easy Trip. (1) The period of pioneering backpacker Umrah of Easy Trip. Period of Project Builder or construction services ranging from the determination of what services will be offered to consumers, target market, to search information with market research, research location, research the legality and also research the market price must be made with a maximum in order to reduce the risk of profit under 20\%. (2) Backpacker Travel trip. Travel planning must have been cooperating with several hotels, transportation, destinations and also other travel agents. Easy Trip already has indeed agreed with the signing of MOU with partner and related partners so that all plans will run smoothly. Consumers in planning the trip is assisted with marketing agents. (3) The Implementation Journey. The implementation of the journey becomes the most important factor because it determines customer satisfaction during the trip, whether it is in accordance with customer expectations. (4) Travel control. Controlling the journey is necessary because each trip must be monitored to avoid any misconduct and other technical errors such as incompatibility with schedules or inaccurate hotel booking confirmations. (5) Operational Period. Operational period made Easy Trip must have a competitive advantage that is by presenting an affordable service and having a good quality of service so that it can make into a positive brand image. (6) Estimated labor requirements. In every implementation of the business, we definitely need the aspect of resources that will run a business or an idea into a business. In some human resource planning, it is necessary to analyze these following things: Job Design, Job Description, Job Value, Human Resource Capacity. Easy Trip recruitment planning starts from: Recruitment, Productivity, Training and Development, Performance Appraisal, Compensation and Benefit, Career Planning, and savings.

Starting from recruitment, training, up to dismissal of labor, each business owner has an SOP that they create to be applied at the company. Based on interviews and observations, it can be stated that the feasibility of doing business backpacker on category management and operational aspect deemed worthy to do as well as developed (Table 4).

The financial aspect is examined is the Payback Period and the company's break-even. Of the three informants backpacker umrah providers, researchers found that the ability of the Payback Period each company is different because their initial business start-up is also different. All informant also stated that in the span of 2 to 4 years of operation, the new states have found their break-even in their business. Table 5 is the financial aspect of the assumption under normal conditions. The main challenge in pricing travel agency services is that pricing structure employed by the provider is based on an individual contract. A possible approach to pricing is component pricing approach, which can be broken down into number of standard components, such as domestic air tickets, international air tickets, accommodation, transaction fees, and travel management (Australian Bureau Statistics, 2014).

Table 5 explain that projected profit always grow every year means that the business can be running because in financial aspect can be accepted. The Table 6 explains that in the year of 2022 Easy Trip has a number of very large cash flow that is as much as Rp $855,809,678$. These funds can be used to increase capacity building facility. 
In a normal plan, Payback Period produce number 2.4924 years which means an initial investment issued will be back after two years and six months the company runs with normal plan (Table 7).

Assumed discount factor is $10 \%$, therefore the normal plan is positive. NPV value of Rp 117,492,770 means that the investment is profitable for Easy Trip because the terms of investment feasibility research is $\mathrm{NPV}>0$, so the project runs decent. Based on interviews and observations, it can be stated that the feasibility of doing business backpacker category financial aspect deemed worthy to do as well as developed (Table 8).

Based on interviews and observation results, it can be stated that the business feasibility of umroh backpacker on the category of financial aspects is considered feasible to be done and developed (Table 9).

Managerial implications are expressed in several aspects, namely marketing, technical, management, law, and financial, managerial implications on the development of Business Umroh Backpacker shows in Table 10. Careful review of any proposal are essesntial before its design and development phase. The formal agreement may lead the process for actual implementations of the process (Mukherjee and Roy, 2017).

\section{CONCLUSION}

Based on the results of the analysis and calculation of several aspect that needing to be studied on the bussiness development feasibility of the backpacker Umrah, it can be drawn some conclusions that are based on the results of the qualitative analysis, that is market and marketing aspect, technical aspect, management and legal aspect, economic, social, and environmental aspect indicate that the pioneering backpacker Umrah and business development are feasible and deserve to be run and developed.

Based on the research results and conclusions that already done, researchers can provide suggestions as follows: (1) For Easy Trip, can follow fellow Umrah entrepreneur community is doing or learning from a backpacker Umrah already had once operates so that the development of the backpacker Umrah Easy Trip can be directional. (2) Further research are advised to use quantitative methods to examine the factors that determine the feasibility of the business so that research results can be in generalities for companies engaged in another backpacker Umrah.

Limitations of this research is needed for researchers to obtain data. It includes five aspect of the competitor: resource person, so there is actual reality that can be acquired more depth and not served. These studies included in the analysis of the text, which base their assumptions on the data that was obtained by investigators for the backpacker Umrah, so the design assumptions and generate any researcher has argued that hanging with the ability of the researcher.

\section{REFERENCES}

Australian Bureau of Satistics. 2014. Travel Agency and tour arrangement services. http://voorburggroup.org

Bause, Katharina; Aline Radimersky; Marinette Iwanicki; Albert Albers. 2014. Feasibilities Studies in the Product Development Process. Procedia CIRP 21. 473 - 478.

Hannert, Arthur. 2010. Feasibility Study of Community Based Tourism in Pinge Bali. https://torismportfolio. files.wordpress.com

Kadariah, L. Karlina dan Gray, C. 2012. Pengantar Evaluasi Proyek. Fakultas Ekonomi Universitas Indonesia. Jakarta.

Kotler, Philip dan Gary, Armstrong. 2012. Principles of Marketing. 14th Edition. New Jersey: Pearson Education Limited.

Muhammad Idwenda Dachyar. 2012. Analisis Kelayakan Investasi dan Resiko Proyek Pembangunan PLTU Indramayu PT PLN (Perseroan). Sidang Akhir Program Magister Manajemen.Univesitas Indonesia.

Mukherjee, Momin and Sahadev Roy. 2017. Feasibility Studies and Important Aspects of Project Management. International Journal of Advanced Engineering and Management. Vol. 2, No. 4, pp. 98- 100.

Namin, Tajzadeh A.A. 2013. Value Creation in Tourism: An Islamic Approach. International Research Journal of Applied and Basic Science. Vol. 4.

OECD. 2017. Financing Approaches for tourism SMEs and Entrepreneurs. OECD Tourism Papers, 2017/03, OECD Publishing, Paris.

Roziq, A., Saleh, M. and Hisamuddin, N., 2016. Analysis Of Business Feasibility Of Cassava Chips and Cassava Tape, Financing and Marketing Strategies for Entrepreneurial Cassava Farmers in Jember Regency.

Suliyanto. 2012. Studi Kelayakan Bisnis: Pendekatan Praktis. Edisi Pertama. ANDI. Yogyakarta.

Suryana. 2013. Kewirausahaan Kiat dan Proses Menuju Sukses. Jakarta: Salemba Empat.

Umar, Husein. 2012. Studi Kelayakan Bisnis (Edisi 2), Teknik Menganalisis Kelayakan Rencana Bisnis secara Komprehensif. Jakarta: Gramedia Pustaka Utama. 
Table 3. Feasibility Criteria of Technical Aspect and Technology

\begin{tabular}{cccl}
\hline No & \multicolumn{1}{c}{$\begin{array}{c}\text { Assessment } \\
\text { Criteria }\end{array}$} & $\begin{array}{c}\text { Eligible/ } \\
\text { Not Eligible }\end{array}$ & \multicolumn{1}{c}{ Description } \\
\hline 1 & $\begin{array}{l}\text { Layout of the Site } \\
\text { clear }\end{array}$ & Eligible & $\begin{array}{l}\text { Strategic, into the road, } \\
\text { google maps }\end{array}$ \\
2 & $\begin{array}{l}\text { Fast and good } \\
\text { service of process }\end{array}$ & Eligible & $\begin{array}{l}\text { Service is fast, friendly, } \\
\text { easy and no ribet }\end{array}$ \\
3 & $\begin{array}{l}\text { Capacity of } \\
\text { facility relief }\end{array}$ & Eligible & $\begin{array}{l}\text { Fairly accommodate 30 } \\
\text { people with 10 cars and } \\
\text { 20 motorcycles. } \\
\text { The new building which } \\
\text { was renovated }\end{array}$ \\
\hline
\end{tabular}

Source: Data processed, (2017)

Table 7. Projected Payback Period Normal conditions (in rupiah)

\begin{tabular}{lrrr}
\hline \multicolumn{1}{c}{ Item } & \multicolumn{1}{c}{ Anmount } & Accumulation \\
\hline Cash Out & 175.000 .000 & - & 175.000 .000 \\
Incoming cash 2018 & 16.717 .500 & - & 158.282 .500 \\
Incoming Treasury 2019 & 96.168 .578 & - & 62.113 .923 \\
Cash go in 2020 & 126.141 .401 & 64.027 .479 \\
Incoming cash 2021 & 217.843 .842 & 281.871 .321 \\
Incoming cash 2022 & 248.938 .356 & 530.809 .678 \\
\hline
\end{tabular}

Source: Data Processed, (2017)
Tabel 4 Criteria Feasibility Management Aspect and Operational

\begin{tabular}{|c|c|c|c|}
\hline No & $\begin{array}{l}\text { Assessment } \\
\text { Criteria }\end{array}$ & $\begin{array}{l}\text { Eligible/ } \\
\text { Not } \\
\text { Eligible }\end{array}$ & Description \\
\hline 1 & Pioneering & Eligible & $\begin{array}{l}\text { With pioneering research } \\
\text { and market analysis } \\
\text { (business plan) }\end{array}$ \\
\hline 2 & $\begin{array}{l}\text { Travel } \\
\text { Planning }\end{array}$ & Eligible & $\begin{array}{l}\text { Planning by doing research } \\
\text { first }\end{array}$ \\
\hline 3 & Implementation & Eligible & $\begin{array}{l}\text { The implementation of the } \\
\text { Umrah journey with SOP }\end{array}$ \\
\hline 4 & Trip Control & Eligible & $\begin{array}{l}\text { Control all Umrah activities } \\
\text { from the Central Office. }\end{array}$ \\
\hline 5 & $\begin{array}{l}\text { Operational } \\
\text { period }\end{array}$ & Eligible & $\begin{array}{l}\text { The company's operations } \\
\text { in the current year }\end{array}$ \\
\hline 6 & Labor & Eligible & $\begin{array}{l}4 \text { people with a different } \\
\text { position. }\end{array}$ \\
\hline 7 & $\begin{array}{l}\text { Labor } \\
\text { recruitment } \\
\text { planning }\end{array}$ & Eligible & $\begin{array}{l}\text { Ranging from recruitment } \\
\text { to labor savings. }\end{array}$ \\
\hline 8 & $\begin{array}{l}\text { Planning and } \\
\text { control }\end{array}$ & Eligible & $\begin{array}{l}\text { Planning and control at the } \\
\text { headquarters of the Easy } \\
\text { Trip. }\end{array}$ \\
\hline
\end{tabular}

Source: Data Procesed, (2017)

Table 5. Projected Profit Loss Easy Trip for 5 years in Normal conditions (in rupiah)

\begin{tabular}{|c|c|c|c|c|c|}
\hline Description & 2018 & 2019 & 2020 & 2021 & 2022 \\
\hline Sales & 825.000 .000 & 1.072 .500 .000 & 1.400 .000 .000 & 1.757 .500 .000 & 1.995 .000 .000 \\
\hline Ticket Cost & 412.500 .000 & 502.612 .500 & 637.776 .600 & 780.837 .864 & 889.785 .294 \\
\hline The cost of hotels in Mecca Medina & 178.750 .000 & 217.798 .750 & 276.369 .860 & 338.363 .074 & 385.573 .627 \\
\hline The cost of Visa/pilgrims & 34.375 .000 & 41.884 .375 & 53.148 .050 & 65.069 .822 & 74.148 .774 \\
\hline The cost of the bus/pilgrims & 13.750 .000 & 16.753 .750 & 21.259.220 & 26.027 .929 & 29.659 .510 \\
\hline Pilgrimage/tour & 17.600 .000 & 21.444 .800 & 27.211 .802 & 33.315 .749 & 37.964 .173 \\
\hline Zam-zam & 1.650 .000 & 2.010 .450 & 2.551 .106 & 3.123 .351 & 3.559 .141 \\
\hline Airport Tax Jakarta-Jeddah/Medina & 4.125 .000 & 5.026 .125 & 6.377 .766 & 7.808 .379 & 8.897 .853 \\
\hline Administration Fee & 6.875 .000 & 8.376 .875 & 10.629 .610 & 13.013.964 & 14.829 .755 \\
\hline Salary Employee & 96.000 .000 & 107.673 .600 & 181.150 .065 & 203.177 .913 & 227.884 .347 \\
\hline Gross Profit & 59.375 .000 & 148.918 .775 & 183.525 .921 & 286.761 .956 & 322.697 .526 \\
\hline The Cost Of Electricity & 9.600 .000 & 9.897 .600 & 10.204 .426 & 10.520 .763 & 10.846 .906 \\
\hline The Cost Of Sanitizing & 4.800 .000 & 4.948 .800 & 5.102 .213 & 5.260 .381 & 5.423 .453 \\
\hline Telephone Charges & 7.200 .000 & 7.423 .200 & 7.653 .319 & 7.890 .572 & 8.135 .180 \\
\hline The Cost Of Advertising Marketing & 9.600 .000 & 9.897 .600 & 10.204 .426 & 10.520 .763 & 10.846 .906 \\
\hline Office Administration Costs & 9.600 .000 & 9.897 .600 & 10.204 .426 & 10.520 .763 & 10.846 .906 \\
\hline Net profit Before tax of $10 \%$ & 18.575 .000 & 106.853 .975 & 140.157 .113 & 242.048 .714 & 276.598 .174 \\
\hline Tax of $10 \%$ & 1.857 .500 & 10.685.398 & 14.015 .711 & 24.204 .871 & 27.659 .817 \\
\hline Net Profit After Tax & 16.717 .500 & 96.168 .578 & 126.141 .401 & 217.843 .842 & 248.938 .356 \\
\hline
\end{tabular}

Source: Data Processed. (2017) 
Table 6. the cash flow projection is an Easy Trip for 5 years in Normal conditions (in rupiah)

\begin{tabular}{|c|c|c|c|c|c|}
\hline Description & Year 2018 & Year 2019 & Year 2020 & Year 2021 & Year 2022 \\
\hline The Initial Cash Flow & - & - & - & - & - \\
\hline Initial Investment & 325.000 .000 & - & - & - & . \\
\hline Cash-Beginning Of Year & 150.000 .000 & 166.717 .500 & 262.886 .078 & 389.027 .479 & 606.871 .321 \\
\hline \multicolumn{6}{|l|}{ Cash Flow Operating Activities } \\
\hline Sales & 825.000 .000 & 1.072 .500 .000 & 1.400 .000 .000 & 1.757 .500 .000 & 1.995 .000 .000 \\
\hline Ticket Cost & 412.500 .000 & 502.612 .500 & 637.776 .600 & 780.837 .864 & 889.785 .294 \\
\hline The cost of hotels in Mecca Medina & 178.750 .000 & 217.798 .750 & 276.369 .860 & 338.363 .074 & 385.573 .627 \\
\hline The cost of Visa/pilgrims & 34.375 .000 & 41.884 .375 & 53.148 .050 & 65.069 .822 & 74.148 .774 \\
\hline The cost of the bus/pilgrims & 13.750 .000 & 16.753 .750 & 21.259 .220 & 26.027 .929 & 29.659 .510 \\
\hline Pilgrimage/tour & 17.600 .000 & 21.444 .800 & 27.211 .802 & 33.315 .749 & 37.964 .173 \\
\hline Zam-zam & 1.650 .000 & 2.010 .450 & 2.551 .106 & 3.123 .351 & 3.559 .141 \\
\hline Airport Tax Jakarta-Jeddah/Medina & 4.125 .000 & 5.026 .125 & 6.377 .766 & 7.808 .379 & 8.897 .853 \\
\hline Administration Fee & 6.875 .000 & 8.376 .875 & 10.629 .610 & 13.013 .964 & 14.829 .755 \\
\hline Salary Employee & 96.000 .000 & 107.673 .600 & 181.150 .065 & 203.177.913 & 227.884 .347 \\
\hline Gross Profit & 59.375 .000 & 148.918 .775 & 183.525 .921 & 286.761 .956 & 322.697 .526 \\
\hline The Cost Of Electricity & 9.600 .000 & 9.897 .600 & 10.204 .426 & 10.520 .763 & 10.846 .906 \\
\hline The Cost Of Sanitizing & 4.800 .000 & 4.948 .800 & 5.102 .213 & 5.260 .381 & 5.423 .453 \\
\hline Telephone Charges & 7.200 .000 & 7.423 .200 & 7.653 .319 & 7.890 .572 & 8.135 .180 \\
\hline The Cost Of Advertising Marketing & 9.600 .000 & 9.897 .600 & 10.204 .426 & 10.520 .763 & 10.846 .906 \\
\hline Office Administration Costs & 9.600 .000 & 9.897 .600 & 10.204 .426 & 10.520 .763 & 10.846 .906 \\
\hline Net profit Before tax of $10 \%$ & 18.575 .000 & 106.853 .975 & 140.157 .113 & 242.048 .714 & 276.598 .174 \\
\hline Tax of $10 \%$ & 1.857 .500 & 10.685 .398 & 14.015 .711 & 24.204 .871 & 27.659 .817 \\
\hline Net Profit After Tax & 16.717 .500 & 96.168 .578 & 126.141 .401 & 217.843 .842 & 248.938 .356 \\
\hline Operational Activities Net Cash & 16.717 .500 & 96.168 .578 & 126.141 .401 & 217.843 .842 & 248.938 .356 \\
\hline Cash Flow Financing Activities & - & - & - & - & - \\
\hline Financing Activities Net Cash & - & - & - & - & - \\
\hline Cash Flow Investing Activities & - & - & - & - & - \\
\hline Investment Activities Net Cash & - & - & - & - & - \\
\hline The Increase In Net Cash & 16.717 .500 & 96.168 .578 & 126.141 .401 & 217.843 .842 & 248.938 .356 \\
\hline Cash-Beginning Of Year & 150.000 .000 & 166.717 .500 & 262.886 .078 & 389.027 .479 & 606.871 .321 \\
\hline Year End Cash & 166.717 .500 & 262.886 .078 & 389.027 .479 & 606.871 .321 & 855.809 .678 \\
\hline
\end{tabular}

Source: Data Processed. (2017)

Table 8. projections of Net Present Value in Normal Conditions (a unit of rupiah)

\begin{tabular}{llrr}
\hline Year & $\begin{array}{c}\text { DF } \\
10 \%\end{array}$ & \multicolumn{1}{c}{$\begin{array}{c}\text { Cash Flow } \\
(\mathrm{Rp})\end{array}$} & $\begin{array}{c}\text { P.V from Cash Flow } \\
(\mathrm{DF} 10 \% \text { x Cash Flow })\end{array}$ \\
\hline 2018 & 0,909 & 16.717 .500 & 15.196 .208 \\
2019 & 0,826 & 96.168 .578 & 79.435 .245 \\
2020 & 0,751 & 126.141 .401 & 94.732 .192 \\
2021 & 0,683 & 217.843 .842 & 148.787 .344 \\
2022 & 0,620 & 248.938 .356 & 154.341 .781 \\
\hline Total & & & 492.492 .770 \\
Investment & & & 375.000 .000 \\
NPV & & & 117.492 .770 \\
\hline
\end{tabular}

Table 9. Eligibility Criteria Financial Aspects

\begin{tabular}{cccl}
\hline No & $\begin{array}{c}\text { Assessment } \\
\text { Criteria }\end{array}$ & $\begin{array}{c}\text { Eligible/ } \\
\text { NotEligible }\end{array}$ & \multicolumn{1}{c}{ Description } \\
\hline 1 & $\begin{array}{l}\text { P a y b c k } \\
\text { Period of less } \\
\text { than 3 years }\end{array}$ & Eligible & $\begin{array}{l}\text { Payback Period of Easy Trip } \\
\text { ranging from 1 year to 2 years } \\
\text { and 3 months. }\end{array}$ \\
2 & $\begin{array}{l}\text { Net Present } \\
\text { Value }>0\end{array}$ & Eligible & $\begin{array}{l}\text { NPV an Easy Trip in the } \\
\text { pessimistic assumptions of } \\
\text { the condition does not deserve } \\
\text { to be executed, but in normal } \\
\text { conditions and very optimistic } \\
\text { feasible }\end{array}$ \\
\hline
\end{tabular}

Source: Data Processed, (2017) 
Table 10 Business Development Managerial Implications Umrah Backpacker

\begin{tabular}{|c|c|c|}
\hline Aspects & Before & After \\
\hline Market Aspects & $\begin{array}{l}\text { Marketing via social media } \\
\text { and from friends to friends }\end{array}$ & $\begin{array}{l}\text { - Follow the national exhibition in Surabaya } \\
\text { - Because the times demand the company to follow the trend, companies create } \\
\text { a Website that is held by one of the employees in order not dormant.mecaame } \\
\text { - Market your services to the community and the Government. } \\
\text { - Pay attention to the implementation of the service and the convenience of } \\
\text { consumers. }\end{array}$ \\
\hline Technical Aspects & $\begin{array}{l}\text { Pay attention to the efficiency } \\
\text { of the business location and } \\
\text { facilities business place }\end{array}$ & $\begin{array}{l}\text { - The addition of a Chair or sofa, the snacks in the waiting room. } \\
\text { - Pay attention to the employees welfare by giving a reward to the best employees } \\
\text { and seeking better wages. } \\
\text { - Pay attention to legality and regulation of any business activities as well as } \\
\text { Umrah. }\end{array}$ \\
\hline $\begin{array}{l}\text { Management } \\
\text { Aspects }\end{array}$ & $\begin{array}{l}\text { Pay attention to labor and } \\
\text { compensation system to run } \\
\text { the company. }\end{array}$ & $\begin{array}{l}\text { - Pay attention to the employees welfare by giving a reward to the best employees } \\
\text { and seeking better wages. }\end{array}$ \\
\hline Legal Aspects & $\begin{array}{l}\text { Have a legality as SIUP, } \\
\text { TDP. }\end{array}$ & $\begin{array}{l}\text { - Pay attention to legality and regulation of any business activities as well as } \\
\text { Umrah journey } \\
\text { - Make NPWP owner or employees. }\end{array}$ \\
\hline Financial Aspect & $\begin{array}{l}\text { Financial statements that } \\
\text { are simple and easy to } \\
\text { understand }\end{array}$ & $\begin{array}{l}\text { - Records of all income and expenditures in detail in order to be recorded in } \\
\text { presentable. } \\
\text { - Perform evaluation of the recording } \\
\text { - financial statements each month. }\end{array}$ \\
\hline
\end{tabular}

Source: Data Processed, (2017) 